\title{
Interpersonal communication tops concerns of farm supervisors
}

\author{
Gregory Encina Billikopf
}

\begin{abstract}
I interviewed 42 farm supervisors in the northern San Joaquin Valley, in order to explore how they became supervisors and how they feel about the work and deal with employee discipline. This study revealed that supervisors generally feel little need for additional training before they take on supervisory responsibilities. Like their farmworker counterparts, supervisors feel good about their jobs, rating them an average of 4.5 on a scale where 5 means the job is fantastic and 1 is terrible. When asked to identify the most challenging and rewarding aspects of their positions, farm supervisors overwhelmingly mentioned their relations with people. Those in upper management were more likely to have fired an employee than firstline supervisors, yet employee discipline was an important aspect of supervisors' work.
\end{abstract}

\author{
T a 1995 study published in a series \\ of California Agriculture reports \\ (Billikopf 1996, 1997, 1999), I explored \\ the attitudes of farmworkers on such \\ issues as farm work and supervisors, \\ hourly versus piece-rate pay, and \\ working for growers versus farm labor \\ contractors. For this last report of the \\ series, I concurrently collected data \\ from farm employers and supervisors \\ in the northern San Joaquin Valley. \\ The objective was to ascertain how \\ farm supervisors felt about their jobs, \\ including the best and worst aspects of \\ their assignments, how they became \\ supervisors and how they dealt with \\ employee discipline. \\ Depending on farm size, growers
} may hire one or more layers of supervisors to oversee farmworkers. First-line supervisors include crew leaders and foremen who deal directly with farmworkers. Middle managers are those supervisors who may oversee first-line supervisors. Farm labor contractors (FLCs) are hired by growers to find and/or manage farmworker crews.

\section{Field interviews}

Data for the entire series was collected between August and October, 1995. Field interviews were conducted in Spanish and English, as needed. The research methods allowed me to interview a broad cross-section of individuals. For example, I spoke to workers who had been in the United States for only two days and would not be found in traditional databases. When I spotted crews from the road, I stopped to conduct individual worker interviews, often with all members of the crew as well as their supervisors. I asked each interview subject 22 questions.

Subjects included 19 first-line supervisors (foreman, assistant barn

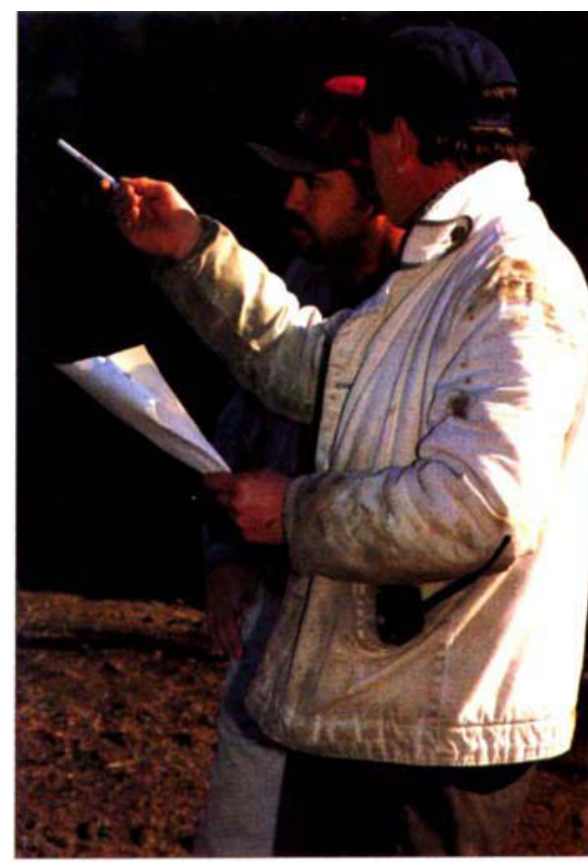

Although employee terminations were infrequent, those in upper management were six times as likely to have fired an employee as compared to first line supervisors.

supervisor, working herdsman, crew leader and lead cowboy), 14 mid- to upper-level managers (supervisor, manager, herdsman and barn supervisor) and nine farm employers (grower, dairy farmer and farm labol contractor).

In order of most frequently to least frequently interviewed, these 42 supervisors worked in vineyard, dairy, almond, peach, bell pepper, livestock, hog, sweet potato, pumpkin and agronomic operations.

Supervisors were mostly male $(95 \%)$, with only two women $(5 \%)$. One of the women was a growes and the other a personnel manager for a large operation. The average time in agriculture in general for supervisors 
was 22 years, ranging from 5 to 48 years. In terms of specific time as a supervisor, the average experience was 14 years, ranging from a little over 2 months to 45 years. The combined total experience in agricultural supervision represented 571 years.

The average age for supervisors was 45 years, the youngest being 20 and the oldest 72 . The ethnicity breakdown was 25 Latino, 10. white, six Portuguese and one Indian (Asian).

\section{Rating the job}

Jobs were rated on a scale of 1 to 5 , in which a "fantastic" job was rated a 5 and a "terrible" job was rated a 1 .

Farm supervisors rated their jobs an average of 4.5 (in contrast with farmworkers, who rated their jobs a 4 [Billikopf 1999]).

Twelve percent of the respondents felt that there was no difficult part to their job. Of the remaining $88 \%$ who identified job stressors, $78 \%$ mentioned labor-related issues, while $22 \%$ spoke about other sorts of stressors.

The comments about job stressors can be broken down (from most to least frequently mentioned) as follows:

Communications and interpersonal relations, $69 \%$. Specific job stresses included instructing and making oneself understood by employees; talking to employees, including disgruntled ones; dealing with the general stress of managing people; trying to please management and employees yet defend company policies or rules, or dealing with piece-rate games; knowing how to supervise and motivate; disciplining and terminating employees; organizing and assigning jobs; being a good listener or counselor to employees; and knowing better English or better Spanish to improve communications.

The issue of piece-rate games was an important one to farmworker crews (Billikopf 1996). At times, employers think they have made a mistake in setting piece rates, and workers end up earning more than what growers think was reasonable. Some growers reduce the piece rate or make the job harder so workers earn less. In effect, employees are punished because they did too well.
Farm supervisors sometimes felt pressured by their superiors to prevent employees from making too much money when paid by the piece. One supervisor stated, "When employees make a lot when piece rate is increased, they make me feel stupid and look bad before the boss." The 1996 study found that as long as farm employers were translating piece-rate earnings into hourly wages - rather than looking at how much they were saving on labor costs per acre when paying by the piece - this type of field stress would continue. On the other hand, when growers realize it is to their advantage to have highearning piece-rate workers, and managed to communicate this philosophy to the employees, everyone wins.

Nature of farming, $16 \%$. Supervisors complained about low milk prices; the 7-day-a-week, 24-hours-aday nature of dairy farming; broken machines; standing in the field on a hot day; sick cows; keeping animal records up to date; stress associated with keeping payroll records and paying farmworkers daily.

Government, $6 \%$. Some farm supervisors said government regulations and compliance requirements are onerous. They also disliked government statements that dairy farmers are subsidized.

Other stresses. In addition, $4 \%$ said they failed to understand their responsibilities, $4 \%$ disliked the pressure for farm labor contractors to provide labor on short notice, and $2 \%$ were finding it difficult to transition from being self-employed to working for someone else.

\section{Best aspects of supervising}

Ten percent of the respondents said nothing stood out as particularly great about their jobs, while $7 \%$ said everything was great. The remaining $83 \%$ offered one or more comments about the best aspects of their jobs: $39 \%$ of the 42 respondents liked working with people; $30 \%$ enjoyed the autonomy, variety and opportunities for learning and challenge; $16 \%$ loved some aspect of farming such as working with the cows or watching trees grow; and 16\% said other positive factors included good or flexible hours, working for a
TABLE 1. Reasons for last employee termination, reported by $\mathbf{2 3}$ farm supervisors in northern San Joaquin Valley

\begin{tabular}{|c|c|c|}
\hline$\%$ & (n) & Reason \\
\hline 26 & (6) & $\begin{array}{l}\text { Insubordination, unwillingness } \\
\text { to follow directions }\end{array}$ \\
\hline 17 & (4) & $\begin{array}{l}\text { Temper tantrums against people, } \\
\text { animals, equipment; verbal abuse }\end{array}$ \\
\hline 13 & (3) & Absenteeism or tardiness \\
\hline 13 & (3) & $\begin{array}{l}\text { Improper task performance } \\
\text { (not doing the job correctly) }\end{array}$ \\
\hline 13 & (3) & Intoxication \\
\hline 4 & (1) & Inflexible about breaks \\
\hline 4 & (1) & $\begin{array}{l}\text { Consistently showing up at work } \\
\text { tired (employee "partied" at night) }\end{array}$ \\
\hline 4 & (1) & $\begin{array}{l}\text { Language barrier (difficult to } \\
\text { communicate instructions) }\end{array}$ \\
\hline 4 & (1) & $\begin{array}{l}\text { Did not complete 1-9 } \\
\text { (INS immigration form) }\end{array}$ \\
\hline
\end{tabular}

TABLE 2. Employee disciplinary corrections, reported by 15 farm supervisors (one had two reasons) in northern San Joaquin Valley

\begin{tabular}{|c|c|c|}
\hline$\%$ & (n) & Reason \\
\hline 50 & (8) & How tasks are carried out \\
\hline 13 & (2) & $\begin{array}{l}\text { Tardiness with absenteeism } \\
\text { (both cases involved alcohol) }\end{array}$ \\
\hline 13 & (2) & $\begin{array}{l}\text { Insubordination } \\
\text { (one case possibly a role confusion) }\end{array}$ \\
\hline 13 & (2) & Vulgar language \\
\hline 6 & (1) & Violence \\
\hline 6 & (1) & Employee told to stop wasting time \\
\hline
\end{tabular}

good farming enterprise with good people, the pay associated with the job and the opportunity to supervise rather than perform the job personally.

\section{Transition to supervising}

I looked at two related issues: (1) how quickly subjects transitioned into their supervisory positions, and (2) if there was anything that could have been done to ease the challenges of the transition.

Speed into first-line supervisory jobs. Of the first-line supervisors, $73 \%$ were farmworkers who were offered the job spontaneously by their direct supervisor or grower/producer (generally with either no notice or about a week to think about it), while $23 \%$ worked their way up from farmworker to a supervisory capacity. In addition, one person applied from the outside.

Reducing difficulty in job transition. Most first-line supervisors (91\%) were satisfied with the support they received from higher management 
during the transition to their new jobs. This was surprising, given the number of challenges associated with being a farm supervisor, as well as the quickness with which first-line supervisors were promoted. Over one-third of these supervisors said their employer had either provided training or the opportunity to observe the person they would be replacing. Only $9 \%$ of the first-line supervisors felt they needed more support during the transition period. One suggested that it would have helped to work along with the previous supervisor for a couple of weeks; another wished there were someone to ask questions if needed.

Looking back at their own careers, middle and upper managers made suggestions for easing the transition into supervisory work. They said farm employers or supervisors should better explain the job duties and requirements, provide an experienced person to coach them and offer interpersonal communications training. One respondent wanted to know why management thought he would make a good supervisor; another felt all went well until the number of employees increased and they fought with each other. One respondent received support from management but had difficulty being accepted by subordinates who had hoped for a different supervisor. For the most part, however, issues of transition into supervisory jobs were not as serious as those related to the handling of employee discipline.

\section{Employee discipline}

Those in upper management were six times more likely to fire an employee $(85 \%)$ than first-line supervisors $(14 \%)$. Respondents recalled having fired the last person as long as 44 years ago and as recently as 2 weeks ago, with an average of a little over 10 years since the last termination. Considering that the average time working as a supervisor was 14 years, it is clear that farm employees are not often terminated. In several instances the distinction between the employees being fired or quitting was blurred, as was the distinction between being fired or simply not rehired the next season. With the exception of two instances,

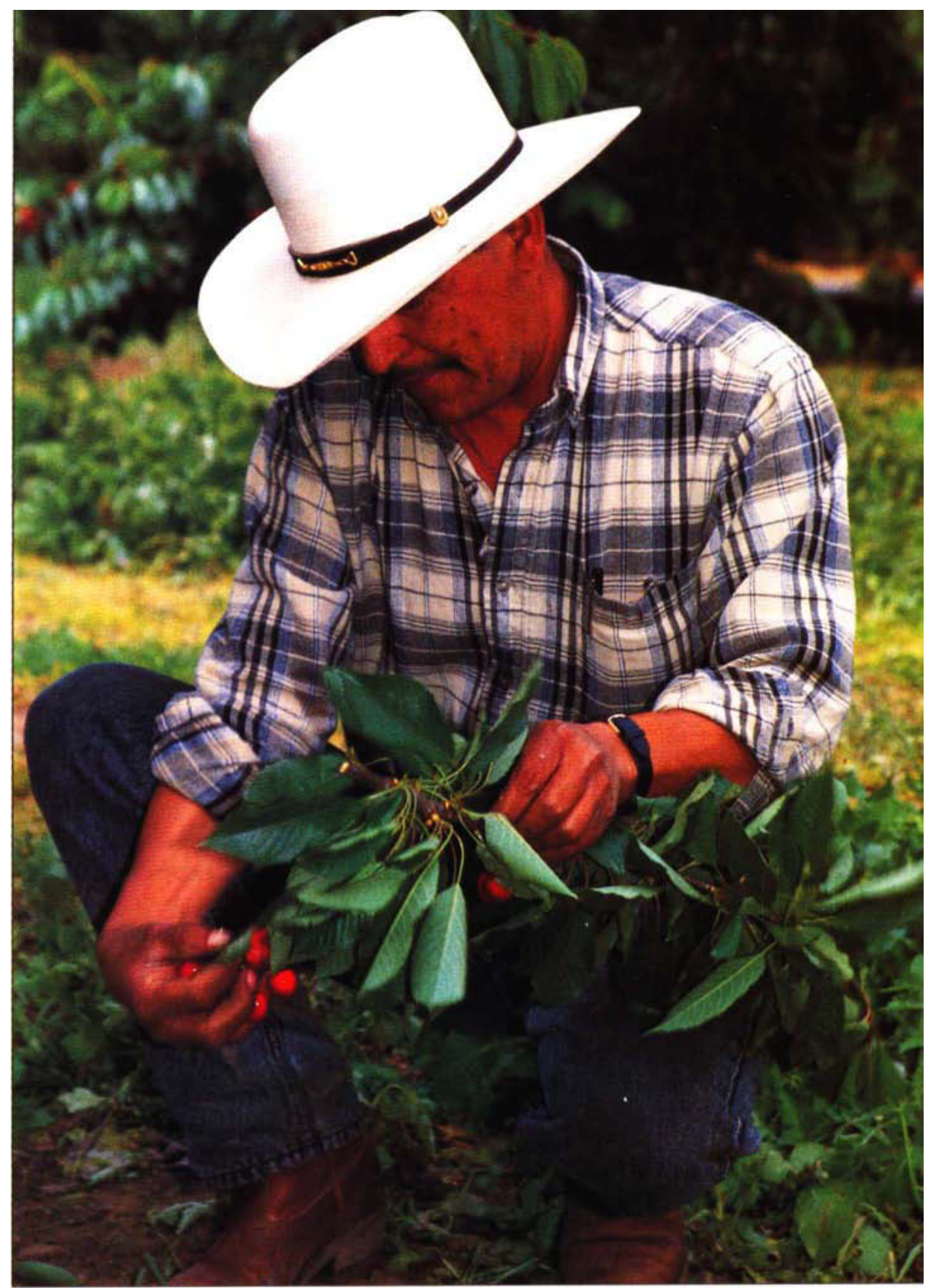

When identifying the most challenging and rewarding aspects of their positions, farm supervisors overwhelmingly selected their relations with people.

the supervisors interviewed recalled the exact grounds for terminating employees (table 1).

Several foremen spoke about their reluctance to terminate employees. In one instance, an employee with a temper was warned five or six times, but was not even fired after he started choking a fellow employee. "I don't want to see this type of behavior," he was told. The employee was eventually fired later that day by his supervisor when his abusive verbal assaults continued. In another case, a picker was warned 20 times before being fired. "I don't like to fire anyone," the foreman explained. "Instead, I try and find something they can do well."

Even after firing an employee, supervisors were prone to forgiveness. "I fired a man twice," a feedlot manager said. "I fired him for hitting the equipment, rehired him, and fired him again for the same reason." One dairyperson explained that when he fired an employee, he did it on the spot because of 
dairy's high vulnerability to sabotage (such as milking a cow on antibiotics into the main tank, where all the milk would be contaminated).

For some supervisors, the term "employee discipline" meant a formal disciplinary procedure, while for others it was more expansive and included correcting an employee or pointing out when something had been done improperly or could be improved. When supervisors were asked when was the last time that they disciplined an employee, more than half $(57 \%)$ said they had not disciplined employees, or explained that their discipline consisted of a simple reminder, correction or telling employees to redo a job.

One supervisor explained that he saw himself in the role of coach and mentor rather than disciplinarian. Another explained that "our people are a hard-working people" who do not need discipline. One foreman remembered what it was like being shouted at as a worker, and made sure not to shout at those he supervised. Another supervisor was philosophical about employee discipline, telling employees "You need the job and I need the job." Yet another supervisor feared that if he made employees look bad in front of the grower, workers would retaliate and make the him look bad in front of the grower as well.

One supervisor appealed to the workers' consciences, asking them to come back if they felt they could complete the job to the satisfaction of the farm employer. On farms where multiple crews are working, and difficulties develop with a direct supervisor, workers sometimes ask or are offered a change in crew. In one case, even when such an offer was made to a crew worker, the worker quit. After being corrected, it was not uncommon for employees to quit, perhaps as a result of having lost face. The most common specific corrections were related to the way a task was carried out, such as how cows were milked or trees picked (table 2).

\section{Supervisors enjoy their work}

We found that farm supervisors from a wide variety of farming occu-

\section{Supervisors' comments}

Supervisors were asked to offer open-ended suggestions to other supervisors and farm employers. Their responses included:

- $\quad$ Tell the workers when they have done a good job and they won't hide errors from you.

- Inform employees about the reasons for changes so they do not take them personally.

- Talk straight across to employees; don't talk down to them.

- Farm employers should provide health insurance.

- Good communication starts at the top.

- Top managers should stop micromanaging and overturning decisions.

- Trouble at home equals trouble at work.
- A good foreman makes a poor worker good; a poor foreman makes a good worker bad.

- Make decisions based on what is best for you rather than what works for a neighbor down the road.

- The boss can become a terror when he or she learns Spanish.

- If the grower can show concern for the employees, $50 \%$ of the battle is won.

- Be patient, don't be pushy, treat employees well.

- I try to be a guide to the people so they can work on their own. pations felt positive about their jobs, generally did not find the transition to supervisory roles difficult, and believed that managing people was the most challenging, although often most enjoyable, part of their jobs. Issues of interpersonal communication, conflict management, piece-rate pay and employee discipline were of special concern. Top and middle managers were six times more likely to have fired an employee, but even then, employee termination was not a frequent occurrence.

While some farm supervisors are not shy about telling employees what they have to do, and terminate them if needed, many are uncomfortable with the process of formal employee discipline and termination; they view themselves more as a coach and "model" worker, showing those they supervise how the job is done.

From this study, it is clear that supervisors love their jobs, and their positive attitudes cut across all races. Most supervisors got their jobs in part because of their knowledge of agriculture. While most foremen felt their transition into supervisory work was easy, farmworkers often wished that supervisors had more training on how to deal with "people" issues. Supervisors would have more confidence dealing with employees if they received training on employee discipline, conflict management, interpersonal relations, power and abuse of authority, negotiation skills and focused listening. Additional research is needed to evaluate the training needs of supervisors, and what training they would consider valuable in order to advance their careers.

G.E. Billikopf is Area Labor Management Farm Advisor, UC Cooperative Extension, Stanislaus County.

\section{References}

Billikopf GE. 1996. Crew workers split between hourly and piece-rate pay. Cal Ag 50(6):5-8.

Billikopf GE. 1997. Workers prefer growers over FLCs. Cal Ag 51(1):30, 32.

Billikopt GE. 1999. Farmworkers positive about their jobs, but suggest improvements. Cal Ag 53(1):33-6. 